\title{
Content-Based Teaching: A Methodological Approach
}

Fernanda Rodríguez Torras

Universidad de Barcelona

\begin{abstract}
The integration of language and content in the foreign language (FL) classroom represents an approach far removed from traditional methodology. This concept would considerably lighten the content of some areas of the curriculum and would require a thoroughly prepared FL staff, and interdisciplinarity in certain areas. In this article I intend to offer some guidelines for the new curricular design occasioned by the reform of Spanish education. They are aimed at various levels, and derive from actual teaching practice.
\end{abstract}

\section{Introduction}

One of the objectives of the European Community is to encourage the acquisition of two foreign languages amongst its citizens, in addition to their own, and to facilitate the movement of people between its member states. The recently established LINGUA Programme $^{1}$ sets out the content of the afore mentioned objectives, which consist principally in the improvement of the quality of foreign language teaching in Europe. Both teachers and students will receive financial assistance towards these aims. The study of a foreign language by non-specialists in foreign languages at a university level will be highly regarded. A foreign language Academy will be created, maintaining close contacts with the various academies of member states. Innovative programmes will be rewarded and studies focussing on multilingualism will be promoted. To summarize, the role of FL teaching is broadening every day and there is a pressing need for its success within five years. My initial thoughts on the subject so far lead me to consider the impact this might have on the Spanish educational system, and especially in those autonomous regions where students learn three languages from the age of eleven, and, as will soon be the case, from the age of eight or nine. At a later date, the incorporation of a second foreign language in the secondary school curriculum will offer many learners the opportunity to study four languages, and the option of exchanges and studies abroad.

In this article, I shall try to outline a conceptual framework which aims to integrate language and content in the teaching of a FL. We have to be aware that this type of 
approach demands a good knowledge of this content (Geography, History, etc.) by the teacher, and interdisciplinarity with some areas of the curriculum. Later on we will consider how this approximation might lighten the content load in the educational reform.

The concept of integrating language and content (Social Sciences, Natural Sciences, Pure Science), in the FL classroom, contrasts with other more traditional methods in which language is learned per se. The theme «Language across the curriculum» provoked interest in Great Britain following the publication in 1975 of the Bullock Report ${ }^{2}$ by H.M.S.O. Its principal ideas, established with a view to the acquisition of a first foreign language, enjoy a high profile in the U.S.A. and Canada under the heading «Whole language theory» (Anderson et al. 707). The most important reasons which led those countries to carry out research in the field of second language acquisition have principally been the high emigration rate and the failure of the educational system, brought about fundamentally by the learning difficulties of pupils with little linguistic competence. I shall begin by enumerating some theoretical principles which form the basis of this concept of language teaching, and I shall move on to specify the most appropriate types of content and methodology, bearing in mind the ages of learners, and their linguistic ability. I shall illustrate my points, with examples of teaching experience carried out in our classrooms, a different and more restrictive situation than that made possible by content based teaching, when the learner lives in the country in which that language is habitually spoken (Ellis Understanding 5).

\section{Theoretical Principles}

There has been growing interest (Brown, Crymes 250-58) in the use of content in the teaching of a FL, among researchers but not among text book writers. This approach is based mainly on the fact that when a child learns his L1, his cognitive and linguistic development is simultaneous. However, this principle does not seem to be taken into account by so called traditional methods, in which there is a need for «a motivating and informative content» (Long et al. 34).

In our own teaching enviroment, M. I. Molina (214) observes, in her empirical research, that the strong polarization of some formal aspects of language has produced very poor results in the learning of English in EGB. In Catalan Secondary Education, in the teaching of English R. Ribe (699) stresses the fact that sequential and synthetic teaching is not the best way to teach a foreign language, and he favours a task-based approach, relying on a wide bibliography and classroom practice. According to this researcher the adoption of a task-based approach represents the optimun way of modifying the network of concepts. C. Coll favours the enrichment of the cognoscitive structure of the adolescent, as far as concerns elements and relations. In referring to the school content he says: «Memory is not only the record of what one has learnt but also the basis from which new learning situations arise» (20). If the cognoscitive structure of the student is rich in elements and relations, his possibility of forming new meanings will be increased.

The idea that foreign language teaching based on task presents an alternative to the structure syllabus stems from the fact that language is something acquired wholistically and not by synthesis. The vision of task as facilitator of interactions through which 
understanding of the imput can be attained is supported by researchers such as R. Ellis (Classroom 83-135), who maintains that the use of this discourse in interaction is the process by which the student acquires knowledge of a L2, if this interaction is meaningful. G. Crookes states in his work (4) that tasks help to direct students towards specific aspects of content and forms of processing information. Consequently, students learn how to acquire information and to practise different conceptual operations necessary to carry out the assigned task. M. Long (89) considers that the task-based syllabus is a form of integration of the four basic stages in syllabus design:

1. The identification of the needs of the learners.

2. Definition of the syllabus content.

3. Organization of the oportunities which lead the student to the acquisition of language.

4. To evaluate the students progress.

C. N. Candlin (29-46) is in agreement with Long on these principles when he says that a first step in teaching from a syllabus of this type is to ensure that purpose, content, and method, or rather the learning experiences, are independent.

J. C. Cummins (8-49) from his standpoint in Canada and U.S.A, states some theoretical principles towards the consideration of integration of language and content. This researcher distinguishes two types of linguistic task: context reduced, and content embedded. Cummins affirms that the former facilitates the acquisition of meaning by the learner, be it because the situation is communicative or because it uses the background knowledge of the student (Carrell et al.), visual elements or contextual clues. This context reduced task presents the learner with great difficulties in coming to an immediate understanding of the meaning, although teachers may facilitate this process with additional help.

B. Mohan favours integrating language and content, because this method offers the students the possibility of communicating in English on a theme which may interest them. Both the language teacher and the content area teacher benefit from this method, by interrelation. Mohan specifies though, that we will have to be very cautious as regards testing, because Grammar and the evaluation of knowledge of a non-linguistic content are very different.

In the United States of America, A. U. Chamot and J. M. O'Malley (227-47) have developed the «Cognitive Academic Language Learning Approach,» C.A.L.L.A., which tries to achieve the development of a linguistic capacity in English by the teaching of content in Social Sciences, Mathematics, and Sciences, in a Foreign language. The programme is followed by students of limited language proficiency who attend special English classes. By attending content classes also and later mainstream classes, a full integration is expected.

In these countries, special programmes of this sort are also conducted for college students. These are of three types: «Theme based,» «Sheltered,» and «Adjunct courses.» D. Brinton, M. Snow and M. Wesche (16-69) offer examples of these models, their content and results. Finally I have to add that in Europe, in Asia, in Australia, and in our context with the «Modular Objectives in Foreign Language Teaching in Catalonia,» there seems to be great coincidence in task use. This approach, which began in 1987, proves that we are working in similar lines, in theory and in practice. ${ }^{3}$ 


\section{Selection of Possible Thematic Content and Its Linguistic Correspondence}

Having in mind a reform of the educational system, we could envisage the possibility that some of the content of certain areas be part of the syllabus of the foreign language teacher with a close relationship between the language teacher and the area specialist. This would lighten the teaching load, and would prevent repetition, in many cases. For example, in the English class of 7 th year EGB, the teacher talks about weather in English. The students learn expresions such as «It is cold,» «It is hot,» «It is foggy,» «It rains,» etc. This class bears no relation to what is being explained in Geography for example: «Climatic zones.» There is no relationship with the curricular content. The knowledge «schemata» that the students may have about the theme are neither used nor stimulated (Carpenter 254-56). There is no reference to the backgroung knowledge the student might have acquired either in his L1 "or L2. If this teacher were to work simultaneously with the Geography teacher or the Social Science teacher, he could interrelate and multiply this knowledge, using maps and tabulations, which might enable the student to draw a graph of rainfall in his home town in comparison with London f. e. We have to acknowledge the fact that this content: the weather, will require a language which is esential to be able to talk about this theme. It is obvious to say that there will be a need not only for functional elements such as notetaking, filling a diagram, etc..

I consider it of interest to mention here the teaching experiences carried out by $M$. Medir (1988) in «Escuela del Profesorado» Tarragona where Dr. Thier (U. C. Berkeley) taught several sessions of the S.C.I.I.S. Programme (Science Curriculum Improvement Study) in English to children with no knowledge of English whatsoever. Because of the nature of the classes, being experimental, the children had no problem following.

The teaching experiences carried out by F. Rodriguez in 1984 at the same college («Let's go to England,» about the weather and transport; «A School Award,» 1985, with the theme of the musical preferences of the students; «Tarragona in Roman Times,» 1986, historical theme; «Hawaii: Its Productions and Customs,» 1987; «Japan: Industry, Religion and Tourism,» 1988; «The Discovery of America,» 1989, and «Barcelona 92: The Olympic Games,» 1990, with children of EGB of the «Escuela Anexa de Prácticas») apply some of these principles. The sessions, usually ten, each case, cover some content with great help of visuals, simplification of written materials, and more stress in comprehension and interaction than in the written production. ${ }^{4}$

The teachers of the «Tarragones» and «Baix Camp» in state schools have worked with seventh and eighth year EGB children in the following themes: «Oil Refineries,» «Shopping in Reus,» «Tourism in Salou,» «Tarragona: The City and its monuments.» In all these examples, the English language has been a medium to approach a stimulating content.

Secondary education offers a greater choice of content. I would advice not to approach only the humanistic knowledge, but also themes of a scientific and technical nature. I do have to acknowledge the fact though, that this type of content presents more difficulties for the foreign language teacher. Teaching through content, projects, and tasks has been well received among several groups of teachers of this level, especially in Catalonia. An interesting feature in the students productions working in this manner, is their creativity. This can be the result of the variety of resources used by the teachers, which facilitate creativity: music, talks, audio visual materials, and a very 
varied bibliography. R. Ribe's «A New Bible» (La llengua anglesa) and N. Vidal's «The Planet» (unpublished) are good examples.

Teaching through content, should revolve around social, geographic, historical and natural science themes. This could take place in the three first years of BUP, to move towards political and scientific themes in COU.

Bearing the reform of our educational system in mind, if this type of content were to be introduced, it would have to be adapted to the linguistic level of the class group. I would mention here some strategies which would produce good results (CantoniHarvey 120-121):

1. A wide use of visuals.

2. A clear specification of the purpose of the theme to be followed.

3. To provide questions the student may answer once he has finished the tasks assigned.

4. Presentation of the difficult vocabulary of the texts: semantic mapping, networks, etc.

5. Helping students to interpret tables and maps.

6. Awareness of the differences in level in reading comprehension among students.

7. Use of simplified texts (good for EGB and BUP).

8. Listening comprehension tasks (interviews, films).

9. Make students aware of the need for a different language skill, according to tasks. 10.Use of games and simulations.

These activities help reading and writing skills when the students

a) Write difficult materials in a simplified form.

b) Write an outline.

c) Practice skimming and scanning techniques in reading.

d) Take notes.

e) Activities of guided writing.

In Spain, generally speaking, our text-books in the teaching of a foreign language, have not used scientific materials, which leads to a poor knowledge of vocabulary in that area. Just by observing an easy experiment, a process, taking notes about each case, the student may reach the stage of being able to write with coherente in paragraph form, helped by the teacher, introducing sequencers when there is need to do so. Furthermore, experiments are a natural context for the use of relations of cause/effect.

Other areas of the curriculum such as plastic arts, though they may need a minor use of language, are adequate for the students to follow instructions, and they are equally suitable for the acquisition of technical vocabulary. I would have to mention too musical content, which should be also present in the foreign language class.

\section{Some Pedagogical Guidelines}

The conceptual framework of the integration of language of content leads us to several considerations. First of all there is a great need for a close collaboration between two 
or more specialists so that part of this instruction, the most approachable to the non specialist, the least conceptual and easier to exemplify, can be taught in the foreign language classroom. Examples could be themes such as: «The routes of the discoverers,» «The industrial revolution» (Scott-Tenant), and generally speaking, the history, the geography, and the literature of the English speaking countries, which are integrated in the curriculum, besides other content, more familiar to the student, be it written in the mother tongue or in the foreign language.

This type of teaching does not require a hierarchy in structural content, of course the presentation of the conditional clause in the first days of class, might be necessary, should the content and its communicative needs demand this level of complexity.

Finally a class based mainly on a structural content, is not able to offer content and concepts which might be motivating enough for the students, while classes which are based on an academic content might be stimulating enough for skills of a higher cognitive level and foster better progress in the acquisition of a foreign language.

\section{Conclusions}

The foreign language classroom, in Primary, Secondary Education and in COU, may integrate language and content in a gradual form, by adapting the language to the content to be taught. This teaching will require great collaboration between the teacher of language and the teacher of content. There must be prior discussion as to the most suitable themes and aspects for the foreign language classroom. Gradually, the curricular content of the foreign language classroom, will shift from an action-situation content, to a more conceptual one, at a later learning stage. This approach requires a curricular renovation, and a staff not only well trained in teaching foreign languages, but ready to instruct his students in a way which may offer them opportunities to learn a stimulating content in a new linguistic code.

\section{Notes}

1. Document of the «Comisión de las Comunidades Europeas», Brussels, January.

2. «A Language for Life» (London: Her Majesty Stationery Office).

3. For a more detailed list see R. Ribe La llengua anglesa.

4. «Let's Go to England.» Basic skills revisited. Quartes Jornades Pedagògiques d'Angles (I.C.E., U.A.B., 1985), pp. 99-117; «A School Award.» L'ensenyament de les llengües estrangeres. Recursos Didactics 6. Barcelona: Generalitat de Catalunya, Departament d'Ensenyament, pp. 5-19. «Tarragona in Roman Times.» L'ensenyament de la llengua estrangera mitjançant continguts curriculars. Comunicació Educativa 1. Subunitat de Didàctiques especials. Departament d'Educació i Psicologia, Universitat de Barcelona. Tarragona, October, 1990, pp. 20-25. «Hawaii: The use of the exotic element in English Content Based Teaching.» In Keeping up to date. Setenes Jornades Pedagògiques. (I.C.E., U.A.B., 1988), pp. 123-41. «Japan»: Unpublished. «The discovery of America.» IX Jornades Pedagògiques per l'Ensenyament de l'Anglès. (I.C.E., U.A.B., February, 1990). To be published. «Barcelona 92: The Olympic Games.» Unpublished. 


\section{Works Cited}

Anderson, J. R., N. Eisenberg, J. Holland, and H. S. Wenicr with C. Rivera-Kron. Integrated Skills Reinforcement: Reading, Writing, Speaking and Listening across the Curriculum. New York: Longman, 1983.

Brinton, D., M. Snow and M. Wesde. Content-Based Second Language Instruction. Ncw York: Ncwbury.

Brown, H. D. and Crymes, eds. TESOL 77: Teaching and Learning English as a Second Language: Trends in Research and Practice. Washington D. C.

Candlin, C. N. «Syllabus Design a critical process.» ELT Documents 188 (1984).

Cantoni-Harvey, G. Content Area Language Instruction Approaches and Strategies. Reading, Mass.: Addison Wesley, 1987.

Carpenter, P. A. The Psychology of Reading and Language Comprehension. Newton, Mass: Allyn and Bacon, 1987.

Carrell, P., J. Devine, D. Eskey, Interactive Aproaches to Second Language Reading. Cambridge: Cambridge UP, 1988.

Chamot, A. U. and J. M. O'Malley «The Cognitive Academic Language Learning Approach.» TESOL Quarterly 21.2: 227-47.

Coll, C. Marc curricular per a l'ensenyament obligatori. Barcelona: Gencralitat de Catalunya, 1986.

Crookes, G. «Task Classification: A Cros;-Disciplinary Review.» Tcehnical Report IV. The Center for Second Language Classruom Research, Social Science Rescarch Institute. University of Hawaii at Manoa, 1986.

Cummins, J. C. «The Role of Primary Language Development in Promoting Educational Success for Language Minority Students.» Schooling and Language Minority Students: A Theoretical Framework. Sacramento: California State Department of Education, 1981.

Ellis, R. Classroom Second Language Development. Oxford: Pergamon Institute of English, 1984.

Understanding Second Language Acquisition. Oxford: Oxford UP, 1985.

Long et al. «The Effects of Teachers Questioning Patterns and Wait Time on Pupil Participation in Public High School Classes in Hawaii for Students of Limited English Proficiency.» Technical Report 1. Center for Second Language classroom Research. Social Science Research Institute. University of Hawaii at Manoa.

Long, M. «The Design of Classroom Second Language Acquisition: Towards Task-Based Language Teaching.» Instructural and Social Implications of Second Language Acquisition Research. Eds. K. Hyltestamn and M. Pienemann. Cleveden: Multilingual Matters.

Mohan, B. Language and Content. Reading, Mass.: Addison Wesley, 1986.

Molina, M. I. Perfiles Interactivos. Unpublished Doctoral Dissertation. University of Granada, 1989

Ribe, R. La llengua anglesa en el cicle secundari d'ensenyament: factors diferencials. Unpublished Doctoral Dissertation. U.A.B., 1988.

Scott-Tenant, Ch. Teaching Experience in COU. Unpublished. Tarragona: I. B. Campclar, 1989. Vidal, N. «The Planct: A Trip within Ourselves.» Long Term Project-Part III. 3rd BUP. Unpublished. Vilanova i la Geltrú: I.B. Manuel de Cabanyes, 1986. 